\title{
Education Quality Guarantee Systems in Ukraine and Hungary
}

\author{
Borkach E. \\ vice-rektor, Ferenc Rákóczi II Transcarpathian Hungarian Institute, Bereghove, Ukraine \\ *Corresponding author: barkatsj@gmail.com
}

Received September 21, 2014; Revised October 30, 2014; Accepted December 14, 2014

\begin{abstract}
The article analyses the characteristics of a quality assurance system of higher education in Ukraine and Hungary in the two past decades. The countries have already established the necessary legislative framework, but a quality assurance system has been operating inefficiently for a long time. Higher education is in need of establishing an independent organization to ensure the quality and enhance quality assurance in higher education.
\end{abstract}

Keywords: quality of education, Bologna process, Ukraine, Hungary

Cite This Article: Borkach E., "Education Quality Guarantee Systems in Ukraine and Hungary.” American Journal of Educational Research, vol. 2, no. 12B (2014): 7-10. doi: 10.12691/education-2-12B-2.

\section{Introduction}

Higher education in Europe is in a state of reform. Main directions of change are defined by pan-European transformation of higher education known as the Bologna process; the ultimate goal is to create a unified and effective higher education. In this process, the issue of quality assurance is particularly important. The role of quality control of higher education increases in direct proportion as the higher education becomes more and more widespread and gains importance in the economy of the country and the continent. At the same time, constant monitoring and quality assurance of higher education is stimulated by increase in the number of students each year set out to study abroad, the growing number of higher education institutions and increase in their competition [10].

Problems of evaluation of quality in higher education in Europe become the subject of interest in the late 1980s. Earlier in the process of mutual recognition of educational achievements the main role was played by the exact determination and harmonization of content of training. Later attention was focused on the study of the conditions of preparation. This greatly increased the interest in achieving the highest possible level and quality of education, and assessment of the quality of training within the institutions and in external independent agencies and partners. The emergence of a large number of students in universities also required more precise and strict regulation [2]. Creation of quality assurance system requires the development of recommendation, guidance documents, a series of legal acts, creation of appropriate structures and mechanisms and sources of funding. This created a need in comparative research and study of the experience of the countries in which the situation in higher education has developed similarly. Ukraine and Hungary are countries that give perfect example of this: they are closely linked shared by a past, intense contacts, and the historical, social and economic development.

Features of quality assurance system of Hungarian higher education in the Bologna process were studied by Gy. Bazsa, J. Bálint, A. Derényi, T. Kozma, I. Polónyi, T. Szántó and others. The scientists analysed the legislation on quality assurance, quality improvement programs, summarized the existing experience with the implementation and quality assurance activities in the Hungarian higher education.

Modern trends in higher education of Ukraine in the context of joining the European higher education system were studied by V. Kremeny, V. Lugovii, M. Bilis'ka, N. Protasova, T. Lukina, V. Oharenko, V. Viktorov, V. Stepko, L. Prokopenko, G. Kryvenko, I. Babyn, V. Beschstnii, Zh. Talanova and others. Almost all of their studies conclude about the low efficiency of governmental structures in the management of quality of higher education, the need for higher educational institutions to acquire genuine autonomy, combined with high responsibility, as it is in European countries.

The goal of this study was to identify common features of quality assurance in higher education in Ukraine and Hungary in 1990-2010 years.

\section{Methods of Analysis}

To reach the goal of the study the author analysed the professional literature, legal and regulatory documents, databases, electronic resources and documentations of universities and governments meant to ensure the quality of higher education in Ukraine and Hungary.

\section{Results and Discussion}


At the beginning of the new millennium, the quality assurance of higher education gained special importance in the context of pan-European transformation of higher education known as the Bologna process. The Bologna process is a typical reform of the late 20th century controlled from above, which is implemented as a series of centralized changes, and quality control is carried out at higher educational establishments. That is why the quality assurance in the Bologna process is somewhat controversial: quality assurance was a new, more widespread form of state control over higher education institutions, through which the government managed to introduce their representatives (coordinators and quality assurance agencies) into higher education establishments, significantly limiting their autonomy self-government [8].

Unlike Ukraine, in Hungary Bologna reform of higher education was carried out simultaneously with the integration into the European Union. However, despite this significant difference, both governments use quality assurance as an excuse to control higher education. This trend is typical for all countries in the region [8]. In both countries, governments are trying to adapt to Western European higher education systems and quality assurance and apply the principles of quality assurance, formulated at different stages of the Bologna process. Differences, that occur both at levels of the organization and at the structure are not significant.

One of the important elements of quality assurance system in the Bologna process is the credit-modular (European Credit Transfer and Accumulation System) system. The credit-modular system at the beginning of its use in the United States had little relation to quality assurance. It probably contributed more to the strengthening of the reliability of teaching, developing the students own way of life based on academic performance and obtained credits, raising the efficiency of education [403]. At the stage of development and initial stages of Credit Transfer System ECTS in Europe it was seen as purely cumulative system, designed to promote individual learning paths of student and achieve higher efficiency of training in higher educational institutions. The quality of education was not an issue when the ECTS was introduced.

The same happened during the implementation of ECTS in Ukraine and Hungary: first, it was seen only as an instrument to organize students training, and then - as means to transfer academic achievements [7]. According to A. Derényi, J. Temesi [4], it happened so that creditmodular system was not meant to guarantee the quality of education, it was meant to guarantee reliability of studies, and optimized system performance. For the first time in Hungary, the credit-modular system was associated with quality assurance of education at the end of 20th century, during the development of criteria of contests quality [2].

The need to identify an unambiguous and understandable system for all institutions that would display all the level and other characteristics of advances acquired in training became particularly significant during the comparison of training in certain areas in different countries. The importance of this question demanded the development of theoretical and methodological principles of requirements towards assessing the quality of training. The combination of credits and quality assurance mechanisms had to bring higher education to a new level.
Monitoring results of credit transfer system conducted in Hungary in the 2005 showed that its tools, processes, regulatory mechanisms, statistical data can be used to improve the quality of higher education. Obviously, the learning activity is so complex, that it cannot be described only through credit-transfer system, without the involvement of a large number of other means. However, A. Derényi and J. Temesiadmit that nowadays without research and analysis of the credit system it is impossible to study the system of higher education or guarantee its quality [4].

The standards of training play a special role in the development of common approaches to evaluate the quality of higher education [6]. The management of higher education in Ukraine is centralized. However, despite this, the national standards of training for the large part of the specializations have not been developed until now. The content and clarity of existing standards is still being under discussion. The Hungarian standards of training outstrip the Ukrainian with its short and simple structure. However, as it is described in Materials of Hungarian Rector's Conference [11], Hungarian standards of training are more like a centralised training plan than the characteristic profile of training. This limits the independence of the institution. The training is burdened by large amount of contact hours. A large number of contact hours hinder the academic mobility of students. Hungarian law on higher education was aimed at developing a system of quality assurance of higher education, to assure that the students will obtain a high level of knowledge that can be used in the domestic and foreign labour market [1]. The Bologna Process aims to develop a system of quality assurance in accordance to unified common principles. The quality control is not just a new name of the state control of higher education. The international studies at the beginning of the 21st century emphasized the possibility of international accreditation in the European higher education, but this idea has not become the practice yet. The accreditation process that was formed in Central Europe in the 1990-s, continues to be a national matter, while the concept of quality assurance relatively quickly appeared in international official documents and subsequently became even more actualized. Thus, the quality assurance has become an instrument of association of higher education in Europe. Exactly these practices and policies affect most the formation of the European higher education. In accordance with the Law on Higher Education in Hungary (ed. of year 2000), the country's higher education institutions are required to establish an internal quality assurance system and take care of the conditions of its functioning in all divisions. The system has to work towards the progressive approximation of the objectives and activities of the institution; focus on the needs of direct and indirect partners, especially students, employers, research promoters, the international and national scientific community.

Institutions, faculties or even smaller units have the right to implement systems of quality assurance (such as «ISO»), which can be confirmed by agencies of external quality assurance, accredited by the Hungarian National Accreditation Committee. Such confirmation is not directly related to the accreditation of the educational establishment by the Hungarian Accreditation Committee 
of Higher Education (HNAC does not gives «ISO» certificates), but the experts definitely have to take into account the availability of the system during accreditation.

All Hungarian universities should have a program of quality improvement, within which the goals of management, planning, monitoring, measurement and evaluation of quality, course of teaching evaluation by students are represented. The management of institution must annually assess the quality and publish the results on its website in acceptable way. The law does not contain an accurate description of program content. However, according to Hungarian professionals, the program had to be an action plan which is prepared for a certain period, based on the analysis of results of the quality assurance system, and it also had to outline the future objectives.

All Hungarian universities were enabled to invite foreign organizations for quality assurance, quality evaluation, and accreditation or for custom consultations. Universities in Szeged and Debrecen were the first that took advantage of this opportunity. Similarly, international or foreign organization may accredit a separate unit or program.

In Ukraine, monitoring and evaluation of the quality of education rely entirely on the state. These tasks are primarily performed by the Accreditation Commission of Ukraine and the State Inspectorate for education which are subordinated to the state. Their activity is regulated by a number of laws and legislations. The competence of the accreditation committee includes licensing and accreditation of the higher educational institutions.

The problem of foundation of criteria for evaluating the quality of teachers as well as students' knowledge cannot be solved once and for all, since it requires constant updating and improvement. The quality assurance and accreditation in higher education in Central European countries are organic satellites, as it is reflected in their motivation and reasoning [12]. According to T. Kozma and A. Juhász terms of accreditation and quality control are used interchangeably [8].

Even a superficial acquaintance with the actual process of accreditation makes it obvious that it is carried out mainly with reference to quality assurance of training. In the region, spread of accreditation was typical for higher education at the end of the last century. At the beginning of the new millennium, under the influence of the Bologna Process, the key issue of higher education was the quality assurance. This fact is explained by some delay of reforms of higher education in Eastern Europe. Countries that have begun the process of accession to the European Higher Education Space with some delay are facing two requirements simultaneously. To ensure the quality of higher education an independent organization for its control is essential, whose role in Hungary is performed by Hungarian National Accreditation Committee (HNAC). Compliance with legal requirements in Hungary is provided by external quality control system.

A similar structure was established in Ukraine in 1998, with the Minister of Education and Science at the head. Tasks related to quality assurance of higher education were divided between the Ministry of Education and Culture (now the Ministry of Human Resource Development), HNAC and educational institutions.

HNAC was formed in 1991. It is a commission organized by the Government of Hungary for the quality control of higher education. It is responsible for the functioning of the national system of accreditation, evaluation of programs and training in institutions, and providing guidance on how to improve their quality. Members of HNAC are appointed by the prime minister on the basis of submissions of universities, research institutions and others, for three years. The representatives of student government and the $\mathrm{PhD}$ students of the country participate in the work of HNAC as non-voting members. HNAC is empowered to make decisions only regarding the doctoral programs. For other levels of training HNAC submits its proposals for approval to the Minister of Education.

Functions of Accreditation Commissions are similar in both countries. Accreditation Commission plays a key role in the Bologna reform of higher education. Without it the licensing and accreditation of training programs and institutions is impossible. Each higher education establishment should monitor and ensure quality within its walls. All training programs and educational institutions must be accredited by an independent expert committee. Accredited higher educational institutions and training programs are periodically re-accredited. An independent expert committee makes conclusions on the results of inspections. Its conclusions are based on the internal introspection of the educational institutions. Obligatory part of accreditation in Hungary is the determination of views of students on the quality of training.

Both Ukrainian and Hungarian State Accreditation Committees formulate high demands towards the quality of the research and teaching staff. The bachelor training is not an exception though it does not exactly match its goals and objectives. In the process of training students to perform practical tasks the professional degree of teacher not always serves as a guarantee of a high level of practical training. Such maximalist demands are justified only during the accreditation of doctoral programs.

In many ways, the role of the Ministry of Education has a leading role in the accreditation as the Minister approves the policy, principles, and the entire industry, control of accreditation; the ministry develops regulations on quality assurance systems in higher education, creates and provides conditions for its activity; hears appeals of higher education institutions on expert opinions of Accreditation Commission; provides annual funding to higher education institutions and accreditation committee, significantly affecting their activities. All sides believe that the quality assurance of higher education is primarily the task of universities; Accreditation Commission plays only a function of external quality control.

Both in Hungary and in Ukraine universities are participating in the work of Accreditation Commission for evaluating the quality level of programs and institutions (licensing examination and accreditation materials of the areas and specialties, preparation of self-examination, admission of expert committees, development and implementation of decisions).

Both Hungary and Ukraine take part in various international organizations to ensure the quality. HNAC recognized and applies the quality assurance system of European standards and principles of quality assurance of domestic education («ESG»).

Thus, despite significant differences in the period of study, the State Accreditation Committee of both 
countries - is a relatively independent organization established to assess training, scientific work, artistic activities and analysis of the quality assurance system in higher education. They perform a number of identical tasks related to quality assurance in higher education, the main ones are:

- Expert assessment of the quality of training at its foundation (licensing);

- Expert evaluation of training (accreditation);

- Harmonization of sectorial system of quality standards of the European Higher Education Area;

- Participation in the development of policy of guidelines and guarantees of the quality of higher education and supervision of the implementation;

- Preparation of a list of experts of higher education.

Based on the examination Accreditation Committee prepares proposals to the Minister on the activities of the institution. In both countries, accreditation committees represent the quality assurance of entire higher education, not individual institutions. Their members and experts advocate the interests not of individual institutions, but common accreditation values, so conflicts of interest often emerge among accreditation commissions and individual universities. According to Gy. Bazsa, T. Szántó, in the struggle of institutions for existence questions the content and quality are increasingly losing their priority [3].

The most important factors that equally affect the maintenance of quality in higher education both in Ukraine and Hungary in the period of study were:

- Environment of domestic and European higher education;

- Regulatory and legal requirements;

- Management of institutions;

- The capacity for objective self-analysis and evaluation of the current state of higher education;

- High demands towards teaching and research staff;

- The availability of necessary resources.

According to I. Polónyi [9], a legislative framework for the introduction of quality assurance in higher education in Hungary began over 20 years ago, but imprecise wording in the regulations, the confusion in terminology, lack of guidance and quality evaluation methods etc. created a long-term obstacles to effective work. This conclusion is quite fair for higher education in Ukraine too.

\section{Conclusions}

At the beginning of the new millennium, the government policy became dominant element of the quality assurance system in Ukraine and Hungary. Even then the quality assurance of higher education in both countries already needed an independent commission on accreditation of quality assurance, enhancing quality assurance in higher educational institutions and creating necessary conditions for this regulatory framework. However, an Accreditation Committee controlled by the Minister of Education can be considered independent only conditionally. It is quite obvious that the system relying solely on state control and evaluation of the quality of education in modern conditions is outdated and ineffective.

\section{References}

[1] “CXXXIX 2005. Law onHigher Education”, HungarianGazette, 160, 9810-9886, 2005.

[2] Bálint, J. "How do the quality assurance system in higher education?” Educatio, 1, 94-110, 2008.

[3] Bazsa, Gy., Szántó, T. "Accreditation of Higher Education is Hungary-Yesterday, today, tomorrow”, Educatio, 1, 36-50, 2008.

[4] Derényi, A., Temesi J. The Credit System and the Quality Assurance”, Educatio, 1, 64-75, 2008.

[5] Dolishniy, M. "Diversification of education in the context of the Bologna process as a prerequisite for improving the quality of human resource capacity”, Ukraine: Aspects of labor, 5, 8-14, 2006.

[6] Holubenko, O., Morozova, T. "The problem of updating higher education in the context of the Bologna reforms", High School, 5, 10-18, 2006.

[7] Kodácsy, T."The credit-optimization in higher education institution working in ECTS”, Hungarian higher education, 7, 1416, 2003.

[8] Kozma, T., Juhász A. "Quality assurance in the "Bologna process". Central European Experience”, Educatio, 1, 52-63, 2008.

[9] Polónyi, I. “Quality assurance in the Higher education”, Educatio, 1, 5-21, 2008. 2008.

[10] Polónyi, I. "Quality assurance in the labor market-oriented higher education”. In.: Bálint Julianna-PolónyiIstván-Siklós Balázs: Quality assurance in the Highereducation.-FKI, Budapest, 10-38, 2006.

[11] Rudas, I. "Bologna Report-2008”. In:Summary of the Hungarian Rectors' Conference, NFKK booklets 3. July 15, 2009. AULA Kiadó Kft., Budapest, 13-18, 2009.

[12] Syebkova, H. "Accreditation and Quality Assurance in Higher Education in Europe: [The Bologna Process], High School, 2, $77-$ 84, 2005. 